\title{
Cellular and Molecular Level Mechanisms against Electrochemical Cancer Therapy
}

\author{
Yeun-Hwa Gu $\mathbb{D}^{1},{ }^{1}$ Takenori Yamashita, ${ }^{2}$ Tota Inoue $\mathbb{C D}^{3},{ }^{3}$ Jin-Ho Song, ${ }^{4}$ and Ki-Mun Kang ${ }^{4}$ \\ ${ }^{1}$ Department of Radiological Science, Faculty of Health Science, Junshin Gakuen University, 1-1-1 Chikushigaoka, Minami-ku, \\ Fukuoka 815-8510, Japan \\ ${ }^{2}$ Department of Radiological Science, Faculty of Health Science, Suzuka University of Medical Science, 1001-1, Kishioka, Suzuka City, \\ Mie 510-0293, Japan \\ ${ }^{3}$ Mie Breathing Swallowing Rehabilitation Clinic, 14-7 Iris Town-cho, Kameyama City, Mie 519-0071, Japan \\ ${ }^{4}$ Department of Radiation Oncology, Gyeongsang National University School of Medicine and Gyeongsang National University \\ Changwon Hospital, 11 Sangjeongja-ro, Seongsan-gu, Changwon City, Gyeongsangnam-do, Changwon 642120, Republic of Korea
}

Correspondence should be addressed to Yeun-Hwa Gu; gu.y@junshin-u.ac.jp

Received 14 December 2018; Revised 10 January 2019; Accepted 16 January 2019; Published 14 April 2019

Academic Editor: Mario M. D'Elios

Copyright (C) 2019 Yeun-Hwa Gu et al. This is an open access article distributed under the Creative Commons Attribution License, which permits unrestricted use, distribution, and reproduction in any medium, provided the original work is properly cited.

\begin{abstract}
Electrochemical treatment (ECT) is a promising new way to induce tumor regression by flowing direct current into the cancer tissue. ECT was applied to different kinds of tumors in clinical studies and showed good results. In addition, basic research has almost not been done in the field of evaluation of efficacy, dose-response, and cytotoxicity. Therefore, the objective is to study the cellular mechanism in the antitumor effect of ECT and to contribute data of basic research of ECT. In the cell-level study, tumor cells (Sarcoma-180, Scc-7, Ehrlich Carcinoma) were studied using ICR mice and C3H mice. In the study group, $\mathrm{pH}$ values of control, $10 \mathrm{~mA} \times 150$ secs, $10 \mathrm{~mA} \times 300$ secs, and $10 \mathrm{~mA} \times 600$ secs groups were measured five times each. In histological level studies, ECT was performed on tumors inoculated on the upper part of the right foot of $\mathrm{C} 3 \mathrm{H}$ mice. In each group, mice were sacrificed by cervical dislocation 6, 12, and $24 \mathrm{hrs}$ after ECT treatment, and tumors were removed. The excised tumor was fixed in tissue with $10 \%$ formalin, and HE staining and apoptosis antibody staining were carried out from the obtained tissue section and observation. In the study at the cellular level, statistically significant differences were observed in all ECT groups in Sarcoma in the tumor growth measurement study compared with the control group. Statistically significant differences were also observed in Scc-7 in all ECT groups compared to the control group. In the intratumoral $\mathrm{pH}$ measurement study, there was a statistically significant difference between the anode and the cathode in each group compared to the control group. In the examination at the histological level, microscopic observation of a slide stained with apoptosis antibody with a magnification of 400 times showed that $6 \mathrm{hrs}$ after ECT it was stronger and then decreased. By performing ECT, a weak current flows in the living body. As a result, changes in tissue $\mathrm{pH}$, generation of gas, etc. occur. In this study, it was also confirmed that the intratumor $\mathrm{pH}$ value becomes strongly acidic on the anode side and strongly alkaline on the cathode side. In addition, this study confirmed the occurrence of gas during treatment of ECT. Changes in the $\mathrm{pH}$ and the like cause changes in the environment in the cell, denaturation of proteins, apoptosis, and necrosis. In this study, a significant increase in apoptosis was confirmed in each ECT group compared to the control group. Treatment effects by ECT were also observed in tumor growth measurement studies and tumor weight measurement studies. From these research results, ECT is considered to be effective as a tumor treatment method.
\end{abstract}

\section{Introduction}

At present, three major therapies (surgical therapy, radiotherapy, and chemotherapy) are the mainstream of cancer therapy. Surgical therapy is a method of surgically removing lesions or tumor cells and normal tissues and can be treated completely only when the cancer remains in the original lesion. Radiotherapy is a local treatment that treats only cancer and surroundings like surgical therapy, but unlike surgical therapy it is a treatment method that does not have to remove the organ. Currently used radiation includes X-rays, $\gamma$-rays, proton beams, heavy particle beams, and the like [1]. 


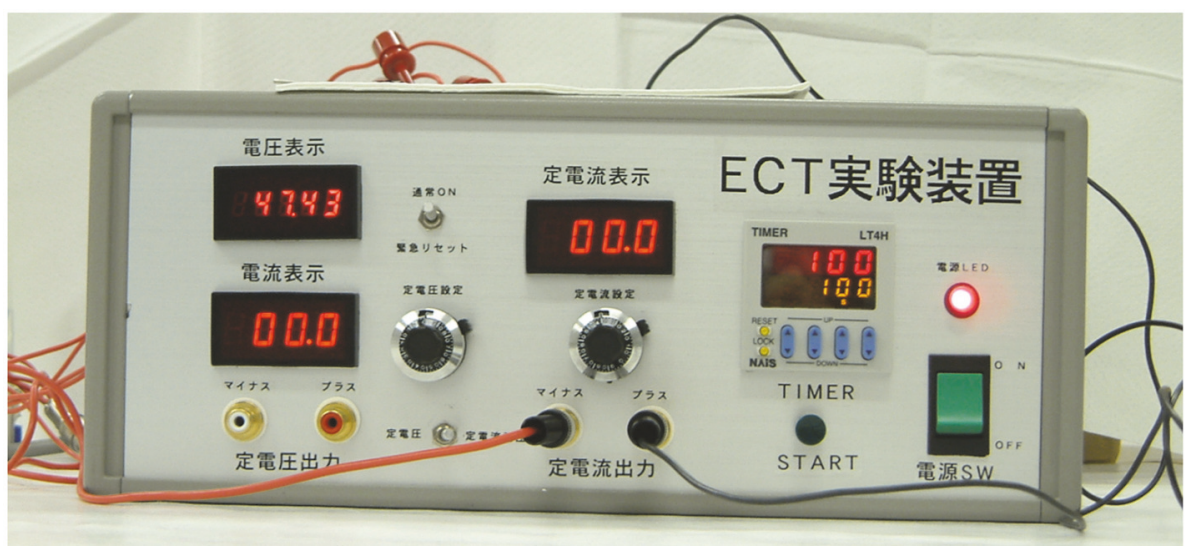

Figure 1: Electrochemical therapy equipment (Sunny Health Co, Tokyo, Japan).

Chemotherapy is a treatment method that uses chemical substances to suppress the division of cancer and kill cancer cells. The anticancer drug enters the blood after administration and destroys the cancer cells surrounding the whole body, so it has a systemic effect. Cancer is called systemic disease, and in the early stage local focal lesion that is limited to a certain site gradually transfers to the whole body and becomes a systemic illness. Surgical therapy and radiotherapy are used to treat local cancers, but chemotherapy is considered to be a more appropriate treatment for cure of systemic diseases. However, side effects such as physical burden and decline in immunity cannot be avoided commonly in the three major treatments. Recent improvements in the quality of life (QOL) of patients are considered, and therapeutic methods with fewer side effects such as immunotherapy have been drawing attention. Currently, these treatments are used alone or in combination [1].

ECT is a promising new method of inducing tumor regression by flowing direct current into the cancer tissue [2-4]. Nodenstrom first used direct current to treat human lung tumors $[5,6]$. Growing fetuses and proliferating tumors are electrically negative to the abdominal wall outside and are more negative than tissue with slower proliferation rate or stagnation. Various studies have been carried out since Humphrey in 1958 reported the disappearance of Sarcoma180 tumor in rats by direct current application in 1958, considering that they could supply electricity from outside and stop tissue growth and proliferation [7, 8]. Xin et al. reported that ECT was performed on more than 6000 different tumors by 1994, and overall the total response (CR) and partial response (PR) were 71.8\% [6].

ECT was applied to different kinds of tumors in clinical studies and showed good results, but almost no organizational study was done in this field.

In addition, fundamental research has not been done in the field of efficacy, dose-response, cytotoxicity evaluation, and the biological mechanism of ECT has not been determined yet. Therefore, in our research, the purpose of the research is to establish ECT mechanism and optimum conditions by using mice. It is aimed to study mechanisms of cellular level and DNA level in the antitumor effect of ECT and to contribute data to fundamental research of ECT.

\section{Methods}

Figure 1 shows the ECT equipment used this time.

$\mathrm{pH}$ measuring instrument: purchased from HORIBA (Model: D-21, Model: EX-20, Power: 9 V DC).

pH electrode: purchased from Fuji Chemicals Co., Ltd. Glass Electrode (special order).

2.1. Studies in the Cellular Level. Closed Coloney's ICR [Crj: $\mathrm{CD}-1]$ mouse and inbred $\mathrm{C} 3 \mathrm{H} / \mathrm{HeNCrj}$ mouse were used at Japan SLC. In order to familiarize themselves with the breeding conditions of this study, we purchased preliminary breeding for one week and used it for research. Rearing conditions were bred under Conventional conditions. The room temperature was $22 \pm 3^{\circ} \mathrm{C}$ and the humidity was 60 to $70 \%$.

In the light control, water and bait (CA-1, Japan CLEA Co., Ltd.) freely ingested the light period of 12 hours from 6:00 A.M. to 6:00 P.M. As a comparative control group, the control group with only tumor inoculation and the antitumor effect group were grouped into 3 groups: tumor $+10 \mathrm{~mA} \times 150 \mathrm{sec}$ group, tumor $+10 \mathrm{~mA} \times 300 \mathrm{sec}$ group, and tumor $+10 \mathrm{~mA} \times$ 600 sec group. In this study, Male mice of 6 weeks of age in each group were used in each group.

\subsection{Tumor Cell. Sarcoma-180 tumor cells are mouse sarcoma cell line.}

Ehrlich-Lettre ascites carcinoma (EAC) is also known as Ehrlich cell. It was originally established as an ascites tumor in mice.

The other cell lines were supplied by the Cell Resource Center for Biomedical Research, Tohoku University (Sendai, Japan) and Riken Cell Bank (Tsukuba, Japan), respectively.

The FSA fibro sarcoma (following Sarcoma) and Ehrlich carcinoma (following Ehrlich) were inoculated into ICR mice and the SCC-7 squamous cell carcinoma (following Scc-7) was inoculated into $\mathrm{C} 3 \mathrm{H}$ mice for research.

Sarcoma and Ehrlich pulled from the mouse intraperitoneally by withdrawing from the mouse and washed the cells several times, so that the cells became about $1 \times 10^{6}$ cells in $0.05 \mathrm{ml}$ of $0.9 \%$ saline and used for research. There was Scc-7 stored in liquid nitrogen, thawed, and warmed 

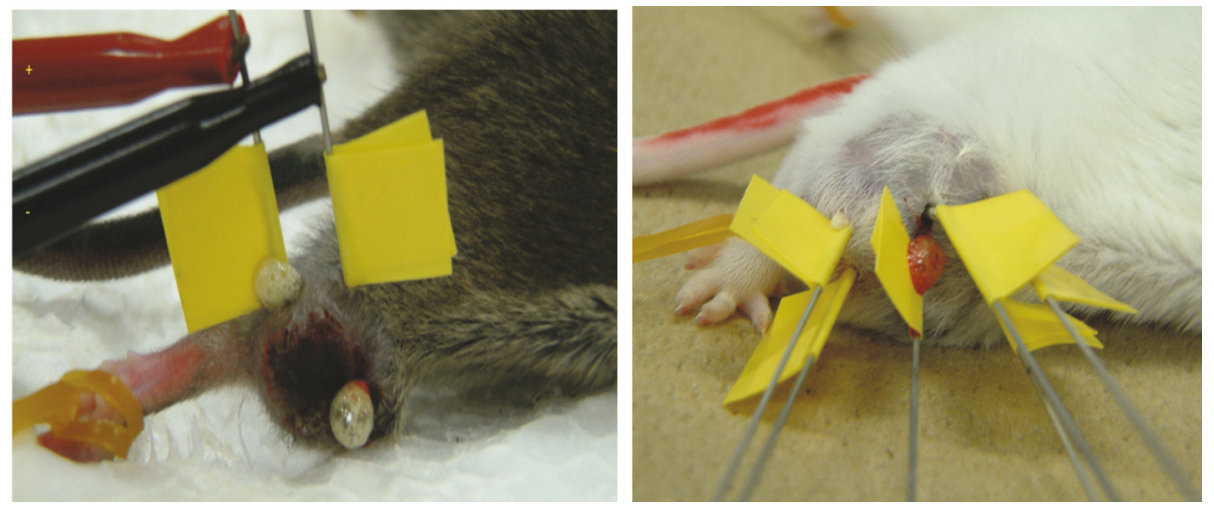

FIGURE 2: Case of electrochemical therapy in the right upper thigh mass. There is $1 \mathrm{~cm}$ distance between the electrodes.

in an incubator with sufficient humidity under $5 \%$ carbon dioxide, mixed with Fetal Bovine Serum in RPMI 1640, and kept in incubator for 2 and 3 months. Approximately $1 \times$ $10^{6}$ cells were poured from the mixed solution and mixed with $0.05 \mathrm{ml}$ serum free medium and used for research. The inoculation sites of Sarcoma, Ehrlich, and Scc-7 were inoculated subcutaneously in the upper right part of the mouse's right foot.

2.3. Anesthesia. Pentobarbital sodium was purchased from Dainippon Pharmaceutical. It was formulated with $0.9 \%$ physiological saline to a concentration of $10 \%$, administered intraperitoneally, and used for anesthesia. The dose concentration was $10 \mathrm{ml} / \mathrm{kg}$ of $10 \%$ Pentobarbital sodium. The study was initiated approximately 10 minutes after peritoneal administration and was used during ECT study.

2.4. ECT Treatment Method/Condition. ECT was performed when the long and short diameter of the tumor inoculated on the upper part of the mouse's right foot reached the size of $2 \mathrm{~cm} \times 2 \mathrm{~cm}$ in Sarcoma (Figure 2).

In Ehrlich and Scc-7, ECT was performed when the major axis and minor axis reached $10 \mathrm{~mA} \times 150$ secs $\times 10 \mathrm{~mA} \times$ $15 \mathrm{secs}$. As treatment conditions, the electrode was inserted throughout the tumor so that the distance between the anode and the cathode was within $1 \mathrm{~cm}$, and ECT was performed under Pentobarbital sodium anesthesia with the currently used $10 \mathrm{~mA}$. Wounds were carefully disinfected with $70 \%$ ethanol before and after the insertion of the electrode.

2.5. Tumor Growth Measurement Study. ECT was performed when the major axis and the minor axis of the tumor inoculated on the upper part of the mouse's right foot reached a size of $2 \mathrm{~cm} \times 2 \mathrm{~cm}$ for Sarcoma. Thereafter, in Ehrlich, Scc7, ECT was performed when the major axis and minor axis became $1 \mathrm{~cm} \times 1 \mathrm{~cm}$ in size, and the growth retardation state of the tumor was observed every day until the 14th day, and the effect of ECT was judged.

The volume of the tumor was calculated by (1) which is generally used from the value measured by vernier caliper.
Tumor volume $\left(\mathrm{mm}^{3}\right)=(\mathrm{ab})^{2}$,

$$
\text { (a: length, b: width) }
$$

2.6. Tumor Weight Measurement. At Sarcoma, Scc-7, the mouse was sacrificed by cervical dislocation on the 14th day after ECT was performed, the tumor was removed, and the weight was measured. Ehrlich also sacrificed the mouse by cervical dislocation on day 33 after performing ECT, and the tumor was removed, and the weight was measured.

2.7. Tumor Inhibition Rate. The tumor inhibition rate was calculated from formula (2) based on the tumor weight.

$$
\text { Tumor inhibition rate }(\%)=\frac{(\mathrm{Cw}-\mathrm{Tw})}{\mathrm{Cw}} \times 100
$$

where $\mathrm{Cw}$ is average tumor weight of the target group and $\mathrm{Tw}$ is average tumor weight of specimen group.

2.8. Tumor pH Measurement Study. Ehrlich tumor cells were inoculated on the upper part of the right foot of the ICR mouse, and ECT was performed when the major axis and the minor axis of the tumor became about $1 \mathrm{~cm} \times 1 \mathrm{~cm}$ in size. Immediately thereafter, a $\mathrm{pH}$ measuring electrode was pierced into the cathode side and the anode side, and the $\mathrm{pH}$ value of the control, $10 \mathrm{~mA} \times 150$ secs, $10 \mathrm{~mA} \times 30$ secs, and $10 \mathrm{~mA} \times 600$ secs group was measured five times each.

\subsection{Review at the Histological Level. Inbred's $\mathrm{C} 3 \mathrm{H} / \mathrm{HeNCrj}$} mouse was used at Japan SLC. Co., Ltd. In order to familiarize themselves with the breeding conditions of this study, we purchased preliminary breeding for one week and used it for research. Rearing conditions were bred under Conventional conditions. The room temperature was $22 \pm 3^{\circ} \mathrm{C}$ and the humidity was 60 to 70\%. In the light control, water and bait (CA-1, Japan CLEA Co., Ltd.) freely ingested the light period of 12 hours from 6:00 A.M. to 6:00 P.M.

As a comparative control group, the control group with only tumor inoculation and the antitumor effect group were grouped into 4 groups: tumor $+10 \mathrm{~mA} \times 15$ secs group, tumor 
$+10 \mathrm{~mA} \times 300 \mathrm{sec}$ group, tumor $+10 \mathrm{~mA} \times 60 \mathrm{sec}$ group, and $10 \mathrm{~mA} \times 150 \mathrm{sec}$ group. In this study, male mice of 6 weeks of age in each group were used in each group.

The SCC-7 squamous cell carcinoma was inoculated into $\mathrm{C} 3 \mathrm{H}$ mice and used for research. Those stored in liquid nitrogen were warmed and defrosted with a sufficiently humidity incubator under $5 \%$ carbon dioxide, mixed with Fetal Bovine Serum in RPMI 1640, and kept in a 2- or 3month incubator. Approximately $1 \times 10^{6}$ cells were poured from the mixed solution and mixed with $0.05 \mathrm{ml}$ serumfree medium and used for research. The inoculation site was inoculated subcutaneously in the upper right part of the mouse's right foot. Pentobarbital sodium was purchased from Dainippon Pharmaceutical. It was formulated with $0.45 \%$ physiological saline to a concentration of $10 \%$, administered intraperitoneally, and used for anesthesia. The dose concentration was $10 \mathrm{ml} / \mathrm{kg}$ of $10 \%$ Pentobarbital sodium. The study was initiated approximately 10 minutes after peritoneal administration and was used during ECT study.

ECT was performed when the major axis and the minor axis of the tumor inoculated on the upper part of the mouse's right foot became $1 \mathrm{~cm} \times 1 \mathrm{~cm}$ in size.

As the treatment condition, ECT was performed under Pentobarbital sodium anesthesia with the electrode injected into the entire tumor so that the distance between the anode and the cathode was within $10 \mathrm{~mA} \times 150$ secs, and the current used was $10 \mathrm{~mA}$.

Wounds were carefully disinfected with $70 \%$ ethanol before and after the insertion of the electrode. ECT was performed on the tumor inoculated on the upper part of the mouse's right foot, and the mice were sacrificed by cervical dislocation (cervical vertebral dislocation) 6, 12, and $24 \mathrm{hrs}$ after each group ECT, and the tumor was removed. The excised tumor was fixed in tissue with $10 \%$ formalin.

Tissue sections of controls and tumor tissues after each treatment were prepared, and the staining method was carried out by Hematoxylin and Eosin $(\mathrm{HE})$ staining, apoptosis stained apoptosis antibody staining with ApopTag ${ }^{\circledR}$ 's KIT.

2.10. Statistical Analysis. All measurements made in this study were shown in average \pm SD. SAS was used for statistical analysis. Parametric ANOVA was used to verify differences in the tumor volume and weight and the number of apoptotic cells in each group. $P$ values less than 0.05 were considered significant.

This study has been approved by the Suzuka University of Medical Science Animal Research Ethics Committee (Ref: 2003/423/15).

\section{Result}

3.1. Study of Cell Level. The average value and standard error of the tumor volume obtained by the measurement and the weight of the tumor after the removal and the tumor suppression rate are shown as the mean value and standard error for each tumor. The horizontal axis represents the number of days elapsed after treatment, the vertical axis represents tumor volume, the horizontal axis represents the study group, and the vertical axis represents the tumor weight

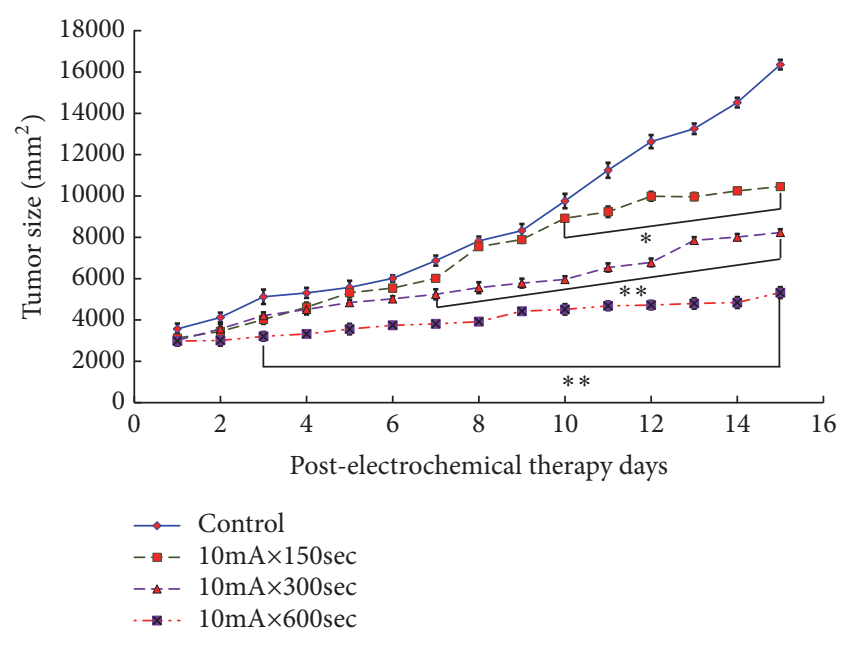

FIgURE 3: Changes of the tumor volume after Sarcoma-180 inoculation in the groups of control, $10 \mathrm{~mA} \times 150 \mathrm{sec}, 10 \mathrm{~mA} \times 300 \mathrm{sec}$, and $10 \mathrm{~mA} \times 600 \mathrm{sec}(* p<0.05, * * p<0.01)$. The results represent \pm S.D. from 8 to 10 mice.

after excision divided by tumor. In addition, the mean value and standard error of intratumor $\mathrm{pH}$ value are shown. The horizontal axis represents the research group, and the vertical axis represents the tumor $\mathrm{pH}$ value. Figure 3 shows the tumor inhibition rate by Sarcoma- 180 cells. A statistically significant difference was observed from the $10 \mathrm{~mA} \times 150 \mathrm{sec}$ group as compared with the control group $(p<0.05)$. A statistically significant difference was observed in the $10 \mathrm{~mA} \times 300 \mathrm{sec}$ group and the $10 \mathrm{~mA} \times 600$ sec group as compared with the control group $(p<0.05, P<0.01)$.

The tumor weight by Sarcoma-180 cells is shown in Figure 4. A statistically significant difference was observed in the $10 \mathrm{~mA} \times 150$ sec group, $10 \mathrm{~mA} \times 300$ sec group, and $10 \mathrm{~mA} \times$ $600 \mathrm{sec}$ group as compared with the control group $(P<0.01)$.

Figure 5 shows the tumor inhibition rate by Scc-7 cells. A statistically significant difference was observed from the $10 \mathrm{~mA} \times 15 \mathrm{sec}$ group as compared with the control group $(p$ $<0.05)$.

A statistically significant difference was observed in the $10 \mathrm{~mA} \times 300 \mathrm{sec}$ group and the $10 \mathrm{~mA} \times 600 \mathrm{sec}$ group as compared with the control group $(p<0.05, P<0.01)$.

The tumor weight by Scc-7 cells is shown in Figure 6 . A statistically significant difference was observed from the $10 \mathrm{~mA} \times 150 \mathrm{sec}$ group as compared with the control group $(p$ $<0.05)$.

A statistically significant difference was observed in the $10 \mathrm{~mA} \times 300 \mathrm{sec}$ group and the $10 \mathrm{~mA} \times 600 \mathrm{sec}$ group as compared with the control group $(p<0.05, P<0.01)$. Therefore, all tumor suppressing effects were observed in the ECT treated group.

Figure 7 shows the tumor inhibition rate by Ehrlich carcinoma. A statistically significant difference was observed from the $10 \mathrm{~mA} \times 150$ sec group as compared with the control group $(p<0.05)$.

A statistically significant difference was observed in the $10 \mathrm{~mA} \times 30 \mathrm{sec}$ group and the $10 \mathrm{~mA} \times 600 \mathrm{sec}$ group as compared with the control group $(p<0.05, P<0.01)$. 


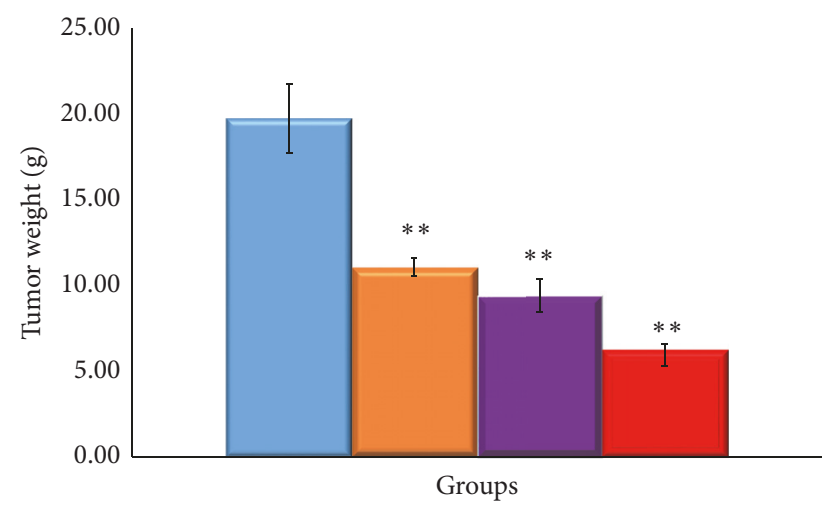

Control

$10 \mathrm{~mA} \times 150 \mathrm{sec}$

$10 \mathrm{~mA} \times 300 \mathrm{sec}$

$10 \mathrm{~mA} \times 600 \mathrm{sec}$

FIgURE 4: Tumor growth-inhibitory effect of ECT in Sarcoma-180 cells-bearing mice. Changes in the weight of the tumor. After tumor implantation, we measured the weight of the fifth week of the tumor of each group. The results represent \pm S.D from 8 to 10 mice. $* *$ Significantly different from the control group $(p<0.01)$.

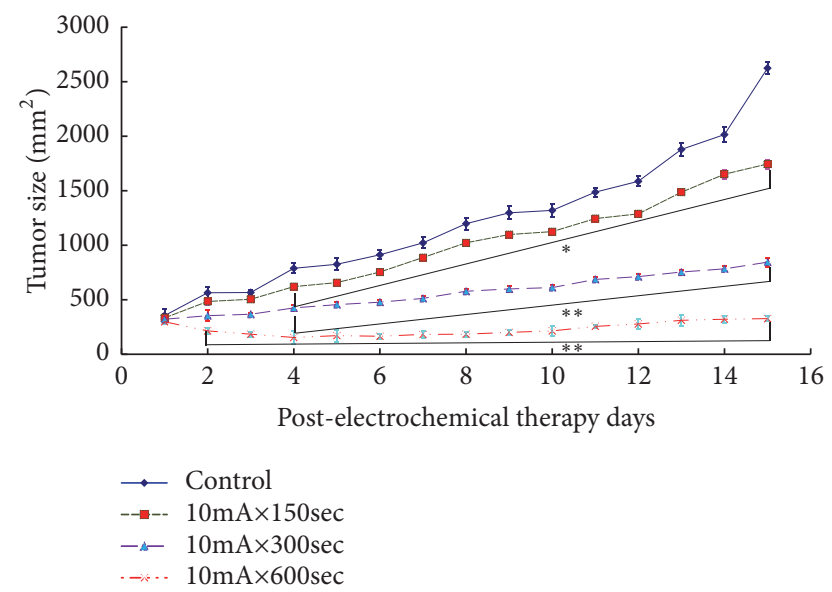

FIGURE 5: Changes of the tumor volume after SCC-7 inoculation in the groups of control, $10 \mathrm{~mA} \times 150 \mathrm{sec}, 10 \mathrm{~mA} \times 300 \mathrm{sec}$, and $10 \mathrm{~mA} \times 600 \mathrm{sec}(* p<0.05, * * p<0.01)$. The results represent \pm S.D. from 8 to 10 mice.

The tumor weight by Ehrlich carcinoma cells is shown in Figure 8. A statistically significant difference was observed in the $10 \mathrm{~mA} \times 150$ sec group, $10 \mathrm{~mA} \times 300$ sec group, and $10 \mathrm{~mA} \times$ $600 \mathrm{sec}$ group as compared with the control group $(P<0.01)$. Therefore, all tumor suppressing effects were observed in the ECT treated group.

$\mathrm{PH}$ measurement on intratumor $\mathrm{pH}$ results on the anode side are shown in Figure 9 and $\mathrm{pH}$ on the cathode side is shown in Figure 10. A statistically significant difference was observed in the anode group and the cathode group compared to the control group $(p<0.01)$.

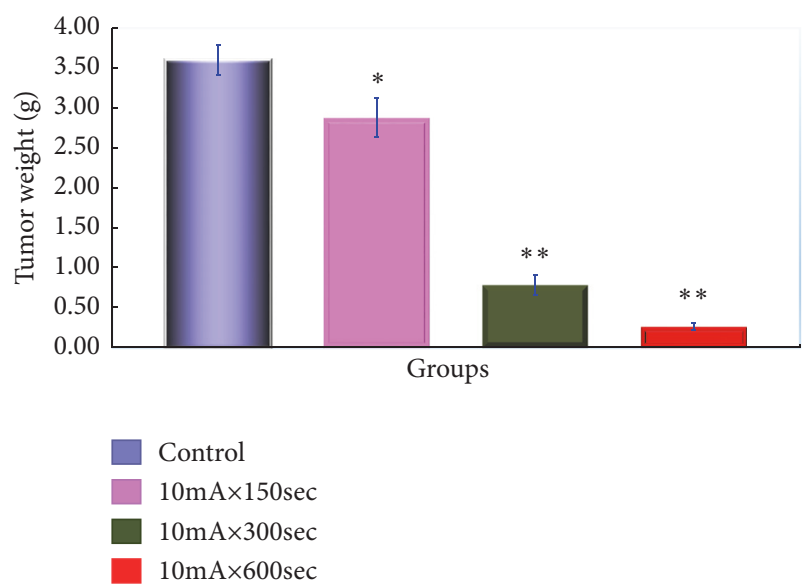

Figure 6: Tumor growth-inhibitory effect of ECT in Sarcoma-180 cells-bearing mice. Changes in the weight of the tumor. After tumor implantation, we measured the weight of the fifth week of the tumor of each group. The results represent \pm S.D from 8 to 10 mice. ** Significantly different from the control group $(p<0.01)$.

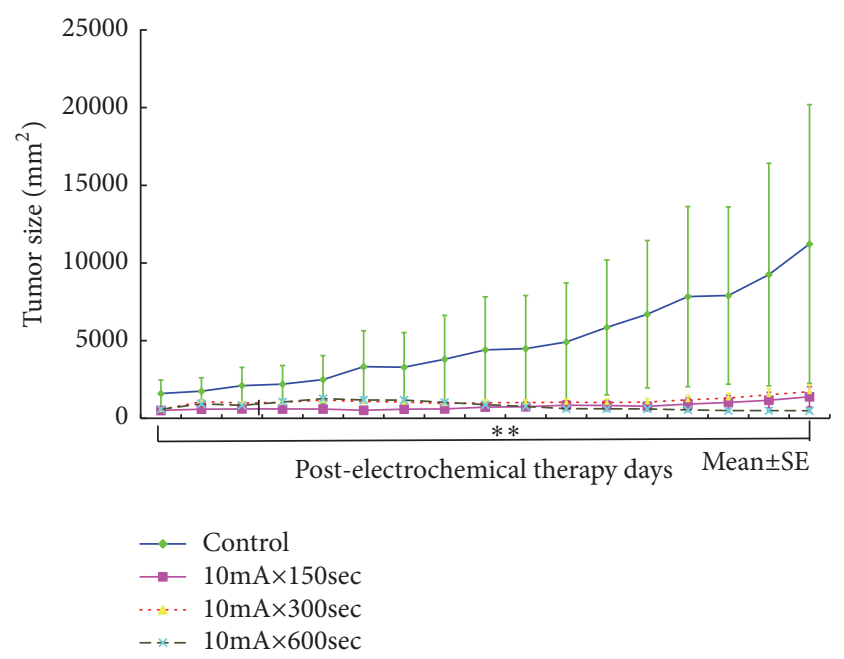

FIGURE 7: Changes of the tumor volume after Ehrlich carcinoma inoculation in the groups of control, $10 \mathrm{~mA} \times 150 \mathrm{sec}, 10 \mathrm{~mA} \times 300 \mathrm{sec}$, and $10 \mathrm{~mA} \times 600 \mathrm{sec}(* * p<0.01)$. The results represent \pm S.D. from 8 to 10 mice.

\subsection{Review at the Histological Level}

HE Staining and Apoptosis Antibody Staining. Figures 11-14 show the changes in the number of apoptosis in each group with microscopic observation of slides stained with apoptosis antibody at a magnification of 400 times. For the observation of apoptosis 6 hours after ECT treatment, a statistically significant difference was observed in the $10 \mathrm{~mA} \times 300 \mathrm{sec}$ group and the $10 \mathrm{~mA} \times 600 \mathrm{sec}$ group as compared with the control group $(p<0.01) .12$ hours after ECT treatment observation of apoptosis showed $(p<0.05)$ in the $10 \mathrm{~mA} \times$ 150 sec group and the $10 \mathrm{~mA} \times 600$ sec group as compared with the control group, and a statistically significant difference in the $10 \mathrm{~mA} \times 600 \mathrm{sec}$ group $(p<0.01)$ was admitted. 


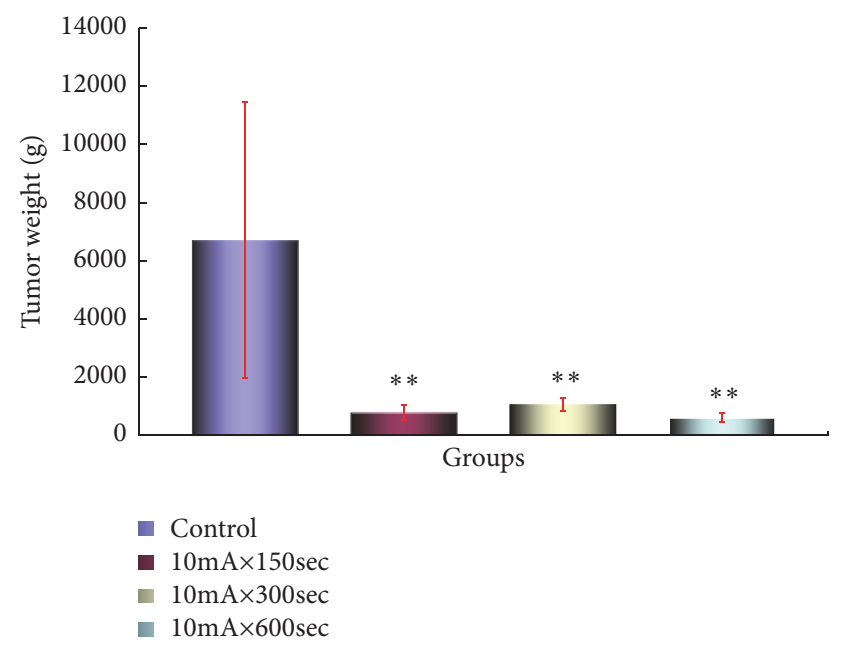

FIgURE 8: Tumor growth-inhibitory effect of ECT in Ehrlich carcinoma cells-bearing mice. Changes in the weight of the tumor. After tumor implantation, we measured the weight of the fifth week of the tumor of each group. The results represent \pm S.D. from 8 to 10 mice. $* *$ Significantly different from the control group $(p<0.01)$.

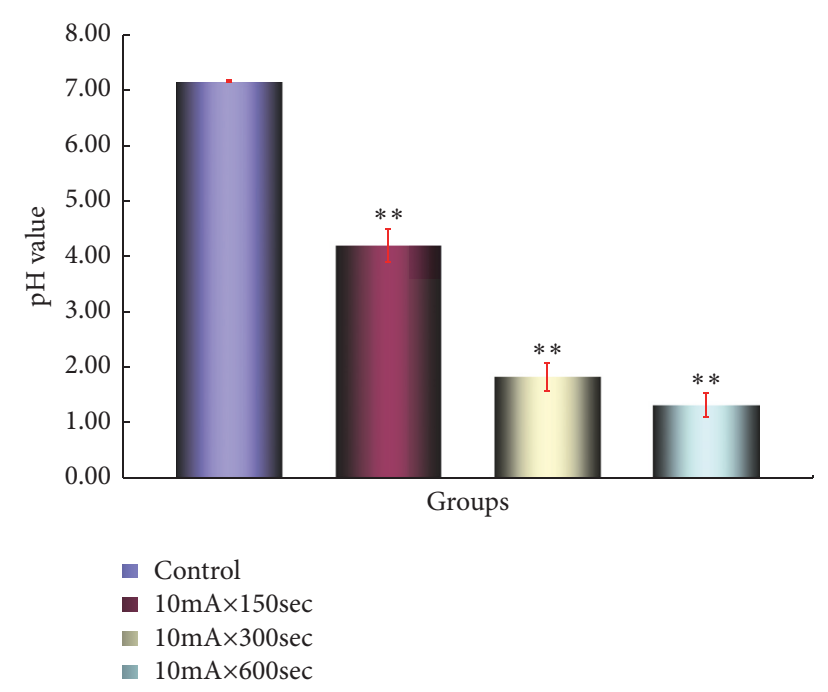

FIgURE 9: $\mathrm{pH}$ in the tumor on the anode side. Each bar represents the mean value SE for 5 points from 8 to 10 mice.. Significantly different $* p<0.05, * * p<0.01$ control vs. $10 \mathrm{~mA} \times 150 \mathrm{sec}$, control vs. $10 \mathrm{~mA} \times 500 \mathrm{sec}$, control vs. $10 \mathrm{~mA} \times 300 \mathrm{sec}, 10 \mathrm{~mA} \times 150 \mathrm{sec}$ vs. $10 \mathrm{~mA} \times 500 \mathrm{sec}$, and $10 \mathrm{~mA} \times 150 \mathrm{sec} v$ s. $10 \mathrm{~mA} \times 300 \mathrm{sec}$.

For the observation of apoptosis 24 hours after ECT treatment, there was a statistically significant difference in the $10 \mathrm{~mA} \times 150$ sec group $(p<0.01)$, the $10 \mathrm{~mA} \times 300$ sec group, and the $10 \mathrm{~mA} \times 600 \mathrm{sec}$ group $(p<0.05)$ as compared with the control group.

Slides of HE staining are shown for each group in Figures 15-17, and pyknosis neoplastic cells are shown in Figure 18.

A statistically significant difference was observed in the $10 \mathrm{~mA} \times 150 \mathrm{sec}$ group, the $10 \mathrm{~mA} \times 300 \mathrm{sec}$, and the $10 \mathrm{~mA} \times$ 600 sec group as compared with thec Control group $(p<0.01)$.

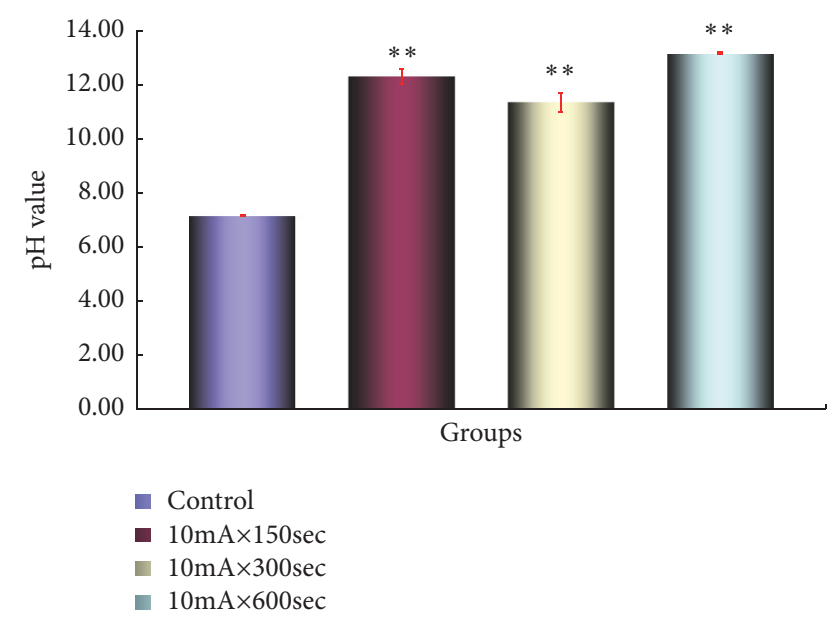

FIgURE 10: $\mathrm{pH}$ in the tumor on the cathode side. Each bar represents the mean value $\mathrm{SE}$ for 5 points from 8 to 10 mice. Significantly different $* p<0.05, * * p<0.01$ control $v s$. $10 \mathrm{~mA} \times 150 \mathrm{sec}$, control vs. $10 \mathrm{~mA} \times 500 \mathrm{sec}$, control vs. $10 \mathrm{~mA} \times 300 \mathrm{sec}, 10 \mathrm{~mA} \times 150 \mathrm{sec}$ vs. $10 \mathrm{~mA} \times 500 \mathrm{sec}$, and $10 \mathrm{~mA} \times 150 \mathrm{sec} v$ s. $10 \mathrm{~mA} \times 300 \mathrm{sec}$.

Slides of HE staining are shown for each group in Figures 15-17, and pyknosis neoplastic cells are shown. Statistically significant difference was observed in the $10 \mathrm{~mA} \times 150 \mathrm{sec}$ group, $10 \mathrm{~mA} \times 300 \mathrm{sec}$ group, and $10 \mathrm{~mA} \times 600 \mathrm{sec}$ group $(p$ $<0.01)$ compared with the control group.

\section{Discussion}

In 1978 Nordenstroem got antitumor effect against lung metastatic malignancy and lung cancer by electrification therapy. Since then, it began to gather attention as a treatment for tumors [5]. Adaptation conditions are solid tumors and are attempted for tumors of all tissue type. In particular, the results of CR + PR exceeding 90\% have been reported in skin cancer, malignant melanoma, superficial squamous carcinoma, vulva cancer, and scar cancer [9]. However, there are still many theories about its principle, but none have been confirmed.

It appears that ECT caused rapid and polar-dependent changes in physiological solutions in cancer tissues, and similar electrochemical processes mediated a decrease in observed tumor growth. ECT is potentially useful as an adjuvant therapy because it reduces the local tumor burden but does not alter the extent of metastasis [5].

According to Xin et al.s research, the anode was inserted into the tumor in lung cancer, and the cathode was inserted from the end of the tumor at least at the distance of the diameter of the tumor, and ECT was performed. As a result, I discovered that it was damaged by the hydration that occurred [10]. From this, as moisture moves from the anode to the cathode by performing ECT, local hydration around the cathode dehydrates around the anode. That is, it is suggested that both the cathode and the anode are effective.

In addition, since the dehydration effect occurs on the anode side, the electrical resistance rises, and the temperature 


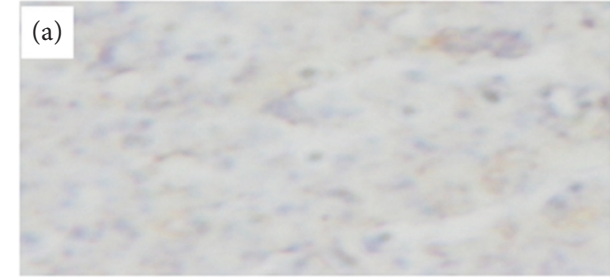

(a)

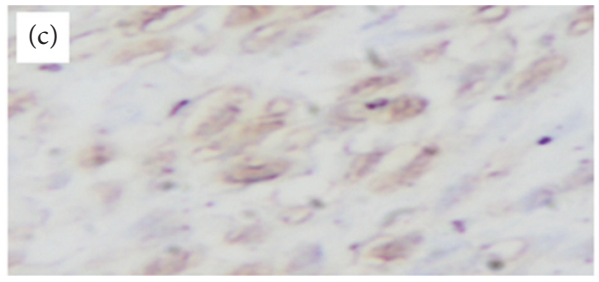

(c)

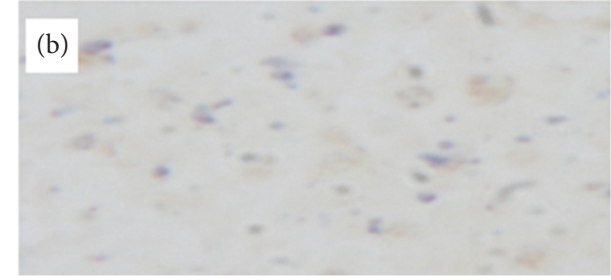

(b)

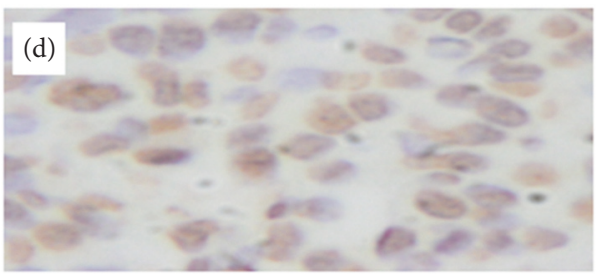

(d)

FIgURE 11: Findings of apoptosis occurring in SCC-7 of C3H mouse after electrochemical therapy. ApopTag ${ }^{\circledR}$ Harris hematoxylin stain. (a) Control group, scattered with few apoptotic cells (x200). (b) $10 \mathrm{~mA} \times 150 \mathrm{sec}$ group with mild degree of apoptosis 6 hours after electrochemical therapy (x400). (c) $10 \mathrm{~mA} \times 300 \mathrm{sec}$ group with moderate degree in apoptosis 6 hours after electrochemical therapy $(\mathrm{x} 400)$. (d) $10 \mathrm{~mA} \times 600 \mathrm{sec}$ group showing marked apoptosis 6 hours after electrochemical therapy (x400). The distribution of apoptosis of the tumor. Quantitation was performed as described in the text and the distribution of apoptotic bodies expressed in relation to position on the tumor cells.

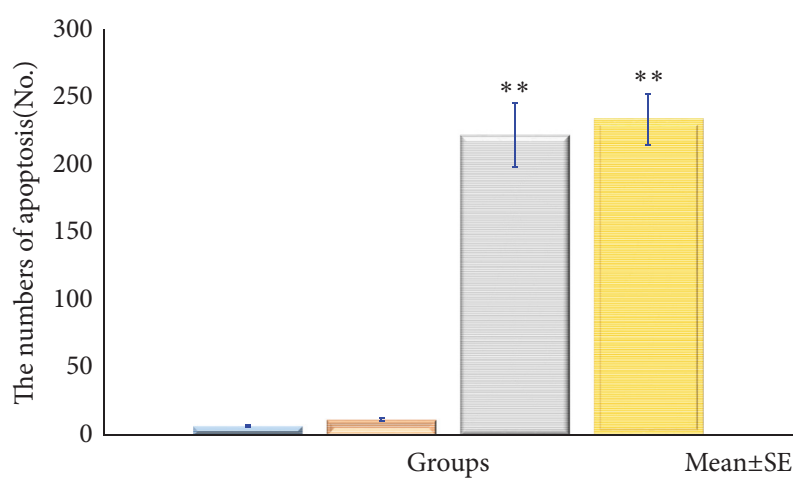

FIGURE 12: The number of cells undergoing apoptosis after electrochemical therapy in $6 \mathrm{hr}$ after treatment. The distribution of apoptosis of the tumor. Quantitation was performed as described in the text and the distribution of apoptotic bodies expressed in relation to position on the tumor cells. Significantly different $* * p<0.01$, control vs. $10 \mathrm{~mA} \times 150 \mathrm{sec}, 10 \mathrm{~mA} \times 300 \mathrm{sec}$, and $10 \mathrm{~mA} \times 600 \mathrm{sec}$. The results represent \pm S.D. from 8 to 10 mice.

of the tissue rises, so it seems that hyperthermia effect may be present.

However, it has been reported that findings by hyperthermia were not observed in local temperature measurements during the ECT performed by Miklavcic et al. [11].

Also, in this study, when observing the slide of $\mathrm{HE}$ staining, hyperthermia effect was not observed, so it is considered that there is no hyperthermia effect in ECT. It has also been reported that treatment with low current for a long time gave better results than treatment with high current for a short time [10].

Even in this study, ECT effect was observed in the $10 \mathrm{~mA}$ $\times 300 \mathrm{sec}$ group and $10 \mathrm{~mA} \times 60 \mathrm{sec}$ group, but in the $10 \mathrm{~mA} \times$

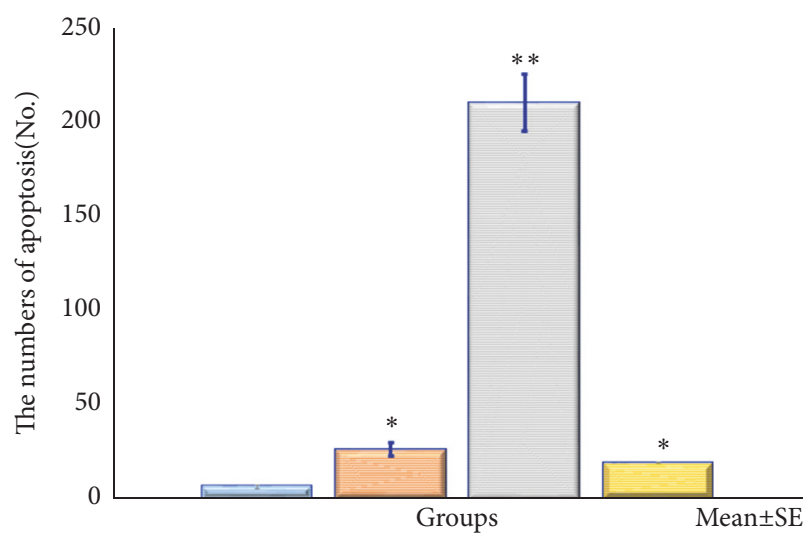

FIgURE 13: The number of cells undergoing apoptosis after electrochemical therapy in $12 \mathrm{hr}$ after treatment. The distribution of apoptosis of the tumor. Quantitation was performed as described in the text and the distribution of apoptotic bodies expressed in relation to position on the tumor cells. Significantly different $* p<0.05$, $* * p<0.01$, control vs. $10 \mathrm{~mA} \times 150 \mathrm{sec}, 10 \mathrm{~mA} \times 300 \mathrm{sec}, 10 \mathrm{~mA} \times 600 \mathrm{sec}$. The results represent \pm S.D. from 8 to 10 mice.

150 sec group, the effect of ECT was not appreciated so much, similar to the report of Xin et al. The amount and treatment time are considered to be important factors in ECT.

According to Ito et al's research, there is a report that confirmed that 5-fluorouracil concentration was remarkably higher in the tumor tissues of the ECT group than in the control group.

This is thought to be the result of anticancer drug being taken into cells of the tumor tissue by opening the $\mathrm{Na}^{-}$and $\mathrm{K}^{+}$channel by ECT. Protein degeneration also occurs by performing ECT. 


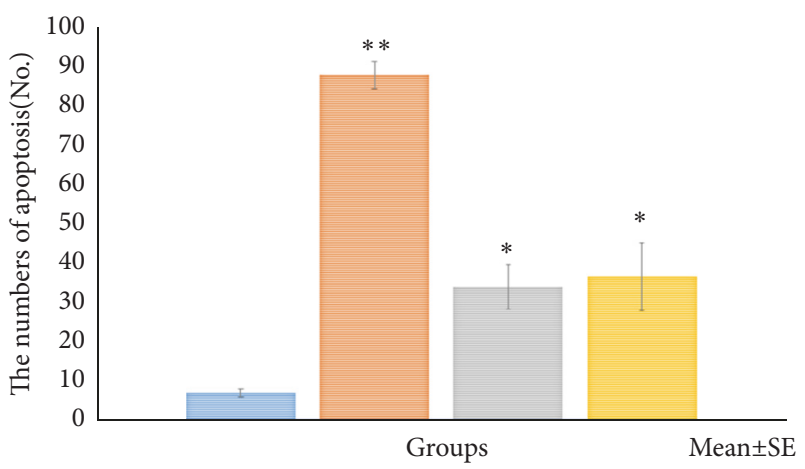

FIGURE 14: The number of cells undergoing apoptosis after electrochemical therapy in $24 \mathrm{hr}$ after treatment. The distribution of apoptosis of the tumor. Quantitation was performed as described in the text and the distribution of apoptotic bodies expressed in relation to position on the tumor cells. Significantly different $* p<0.05, * * p<0.01$, control vs. $10 \mathrm{~mA} \times 150 \mathrm{sec}, 10 \mathrm{~mA} \times 300 \mathrm{sec}$, and $10 \mathrm{~mA} \times 600 \mathrm{sec}$. The results represent \pm S.D. from 8 to 10 mice.

Studies using Li et al. reported that radioimmunoassay markedly decreased albumin and globulin around the cathode and anode in dog liver. According to Ito et al's research, hemoglobin is converted into iron (III) protoporphyrin chloride $\left(\mathrm{C}_{34} \mathrm{H}_{32} \mathrm{ClFIIIN}_{4} \mathrm{O}_{4}\right)=$ chlorohemin which is acidic Hemin on the anode side and iron (III) protoporphyrin $\left.\left(\mathrm{C}_{34} \mathrm{H}_{32} \mathrm{O}_{4} \mathrm{~N}_{4} \mathrm{FeOH}\right)\right)=$ Hematin (hematin) has also been reported to occur [12].

A research report has been made that in the in vitro study using Yun et al.s Human KB Cells, the pH is 4.53 around the anode and 10.46 around the cathode and the $\mathrm{pH}$ returns to 7.5 after 24 hours [13].

In the in vivo study using mouse Scc-7 cells in this study, the intratumoral $\mathrm{pH}$ value was 4.20 at $10 \mathrm{~mA} \times 150$ secs and 1.82 at $10 \mathrm{~mA} \times 300$ secs around the anode and $10 \mathrm{~mA} \times$ 600 secs.

It was confirmed that the $\mathrm{pH}$ value was changed to strongly acidic with 1.31 at the periphery of the cathode, 12.31 at $10 \mathrm{~mA} \times 150$ secs, 11.37 at $10 \mathrm{~mA} \times 300$ secs, and 13.15 at $10 \mathrm{~mA}$ $\times 600$ secs.

Since this result is similar to that reported by Yun et al., ECT was found to have a therapeutic effect due to $\mathrm{pH}$ change. Changes in intracellular $\mathrm{pH}$ are indicated in the same way as changes in extracellular $\mathrm{pH}$; for example, $\mathrm{H}^{+}$increases and as the extracellular $\mathrm{pH}$ decreases, intracellular $\mathrm{pH}$ decreases. Because it is strongly alkaline around the cathode, it causes liquefaction necrosis and the activity of the cell is quickly lost because it is strongly acidic around the anode. In addition, the intracellular alkalization increases the flow of calcium, resulting in an increase in intracellular $\mathrm{Ca}^{2+}$. Since $\mathrm{Ca}^{2+}$ in electrolyte is a determinant in toxicological processes in various pathologies, cellular disorder occurs when the intracellular $\mathrm{Ca}_{2}{ }^{+}$stability breaks down. When $\mathrm{Ca}^{2+}$ becomes excessive, it is thought that $\mathrm{Ca}^{2+}$ plays an important role of killing the cell, since it can cause cell death.

Changes in the intracellular $\mathrm{pH}$ and the shape of the ions in the cell are thought to cause apoptosis [14-16].
In 1995, a study using Yoshida sarcoma cells in Ito et al.d Dynasty Rat also showed a faint ladder pattern by DNA agarose gel electrophoresis by Wyllie's method and a nucleus by nick-end labeling method. The positive staining of the stain is recognized [17].

In this study, apoptosis antibody staining was performed instead of agarose gel electrophoresis or nick-end labeling method; it was found that after hrs it changed to $10 \mathrm{~mA} \times$ 300 secs and $10 \mathrm{~mA} \times 600$ secs group, after $1 \mathrm{hr}$ it changed to $10 \mathrm{~mA} \times 300$ secs group, and after $24 \mathrm{hrs}$ there was a significant increase in apoptosis in each group compared to the control group. In addition, occurrence of apoptosis was confirmed particularly in the vicinity where the electrode was inserted.

This result is similar to Ito et al's, and it is certain that ECT causes apoptosis. This result suggested that the effect of apoptosis on tumor treatment is present in ECT. From this result, when the condition for treating ECT is as low as $10 \mathrm{~mA}$ $\times 150$ secs, the time at which apoptosis occurs depending on the condition to treat at $10 \mathrm{~mA} \times 300$ secs, $10 \mathrm{~mA} \times 300$ secs, when the condition is as high as $10 \mathrm{~mA} \times 600$ secs, after $6 \mathrm{hrs}$, after $12 \mathrm{hrs}$, and after $24 \mathrm{hrs}$, it seems that there is a difference between them.

Also, by performing ECT, high concentration of $\mathrm{Na}^{+}, \mathrm{K}^{+}$ is confirmed around the cathode, and high concentration of $\mathrm{Cl}^{-}$around the anode has been confirmed. Other ions $\mathrm{Ca}^{2+}, \mathrm{Mg}^{2+}, \mathrm{Mn}^{2+}, \mathrm{Cu}^{2+}$, and $\mathrm{A}^{13+}$ also for them to integrate moving speed inversely proportional to the magnitude of the diameter of the atoms, $\mathrm{Na}^{+}$, later compared to $\mathrm{K}^{+}$, for the movement difference $\mathrm{Na}^{+}, \mathrm{K}^{+}$more accumulates around the cathode. Nerve excitability occurs due to more $\mathrm{Na}^{+}$ and $\mathrm{K}^{+}$gathered. When cells are subjected to appropriate physicochemical stimuli, the ion permeability of the cell membrane changes rapidly, resulting in stimulation and changes.

The generation of this action potential is called excitation, and the cell membrane having the excitability, and the excitability by exciting property according to the stimulation is called an excitable membrane. Although it has nothing to do with this study directly, it is certain that such a thing also causes some changes in the tumor as it is caused by ECT.

Radicals oxidized by $\mathrm{Cl}_{2}, \mathrm{O}_{2}$, and $\mathrm{O}_{3}$ are adsorbed on the anode [18], which in turn certainly causes necrosis [19]. In the vicinity of the cathode, oxygen causes necrosis to be expelled from the tissue by hydrogen. Even in this study, it was confirmed that necrosis was caused by HE staining of tissues, so ECT caused necrosis. As described above, it is considered that ECT principle is to change the electrolyte concentration of the cytoplasmic substrate by changing the intracellular $\mathrm{pH}$, thereby inducing cell damage and cell death.

In this study, the tumor suppressing effect of $\mathrm{Scc}-7$ was observed in the $10 \mathrm{~mA} \times 300 \mathrm{sec}$ group and the $10 \mathrm{~mA} \times 600 \mathrm{sec}$ group.

This is similar to the study by Yun et al. By passing electricity through, $\mathrm{pH}$ of the tumor is attracted on the anode side, $\mathrm{Cl}_{2}$ is generated by binding binds $\mathrm{H}_{2} \mathrm{O}$ in the tissue, $\mathrm{Cl}_{2}$ generated, and $\mathrm{HCl}, \mathrm{HClO}, \mathrm{Na}^{+}$attracted to $\mathrm{OH}^{-}$ on the cathode side changed to strongly alkaline by $\mathrm{NaOH}$ generated, which is thought to be the result of affecting tumor cells [20]. 


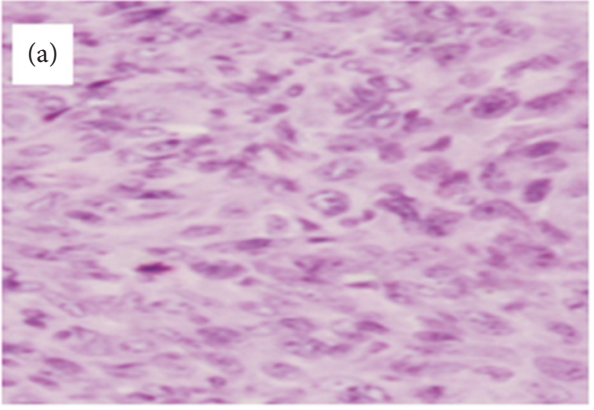

(a)

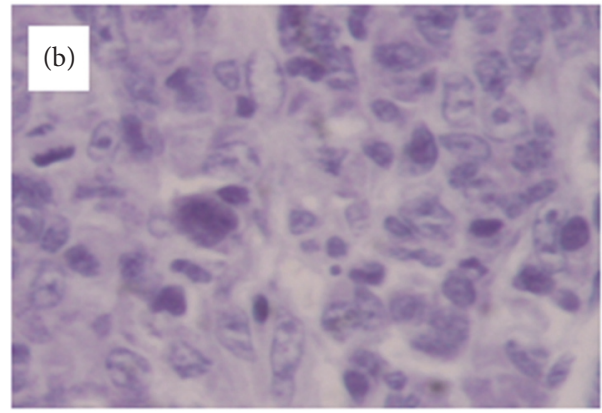

(b)

FIGURE 15: Microscopic finding of squamous cell carcinoma $(1 \mathrm{xl} \mathrm{cm})$ occurring on the right upper thigh after inoculation of SCC-7 in control group (a) and $10 \mathrm{~mA} \times 600 \mathrm{sec}$ group (b). (a) There are mainly well-differentiated spindle cells with whirled solid pattern and some mitotic figures (H \& E, x200). (b) Tissue section taken 6 hours after treatment in experimental group received 1 coulomb. There are fully differentiated spindle cells without difference comparing control ( $\mathrm{H} \& \mathrm{E}, \mathrm{x} 400)$.

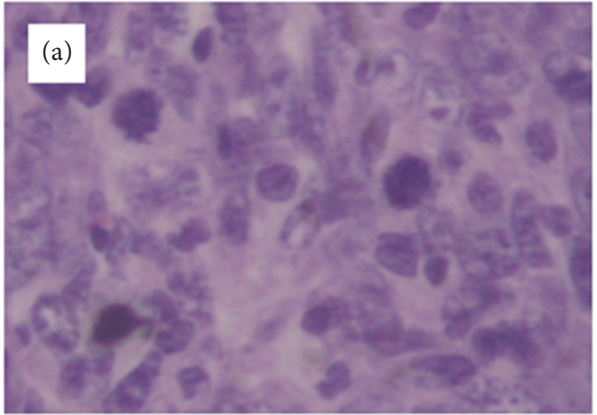

(a)

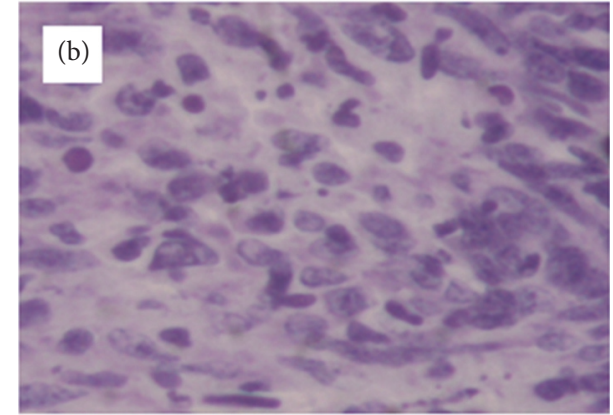

(b)

FIGURE 16: Microscopic finding of squamous cell carcinoma $(1 \mathrm{~cm} \times 1 \mathrm{~cm})$ occurring on the right upper thigh after inoculation of SCC-7 in $10 \mathrm{~mA} \times 600 \mathrm{sec}$ group. (a) Tissue section taken 6 hours after treatment. There is focal cellular apoptotic body of SCC (H \& E, x400). (b) Tissue section taken 24 hours after treatment. There is destructive change including moderately fragmented and necrotic neoplastic cells (H \& E, $\mathrm{x} 400)$.

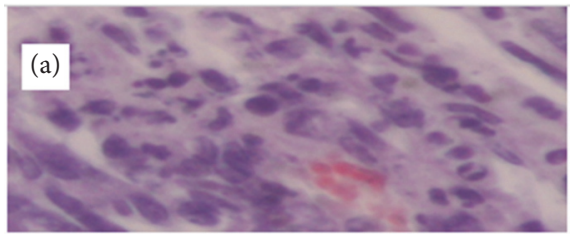

(a)

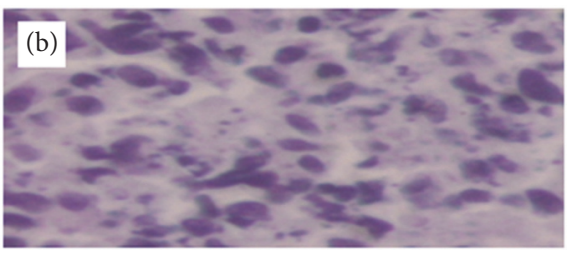

(b)

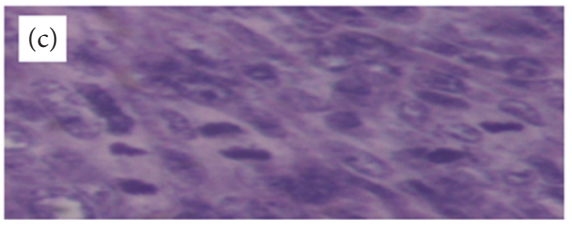

(c)

FIGURE 17: Microscopic finding of squamous cell carcinoma $(1 \mathrm{xl} \mathrm{cm})$ occurring on the right upper thigh after inoculation of SCC-7 in $10 \mathrm{~mA} \times 600 \mathrm{sec}$ group. (a) Tissue section taken 6 hours after treatment. There are many pyknosis neoplastic cells and also some typical spindle cells with mitosis ( $\mathrm{H} \& \mathrm{E}, \mathrm{x} 400)$. (b) Tissue section taken 12 hours after treatment. There are many destructive neoplastic cells (H \& E, $\mathrm{x} 400)$. (c) Tissue section taken 24 hours after treatment. There are diffuse, numerous cellular debris derived from neoplastic cells (H \& E, $\mathrm{x} 400)$. 


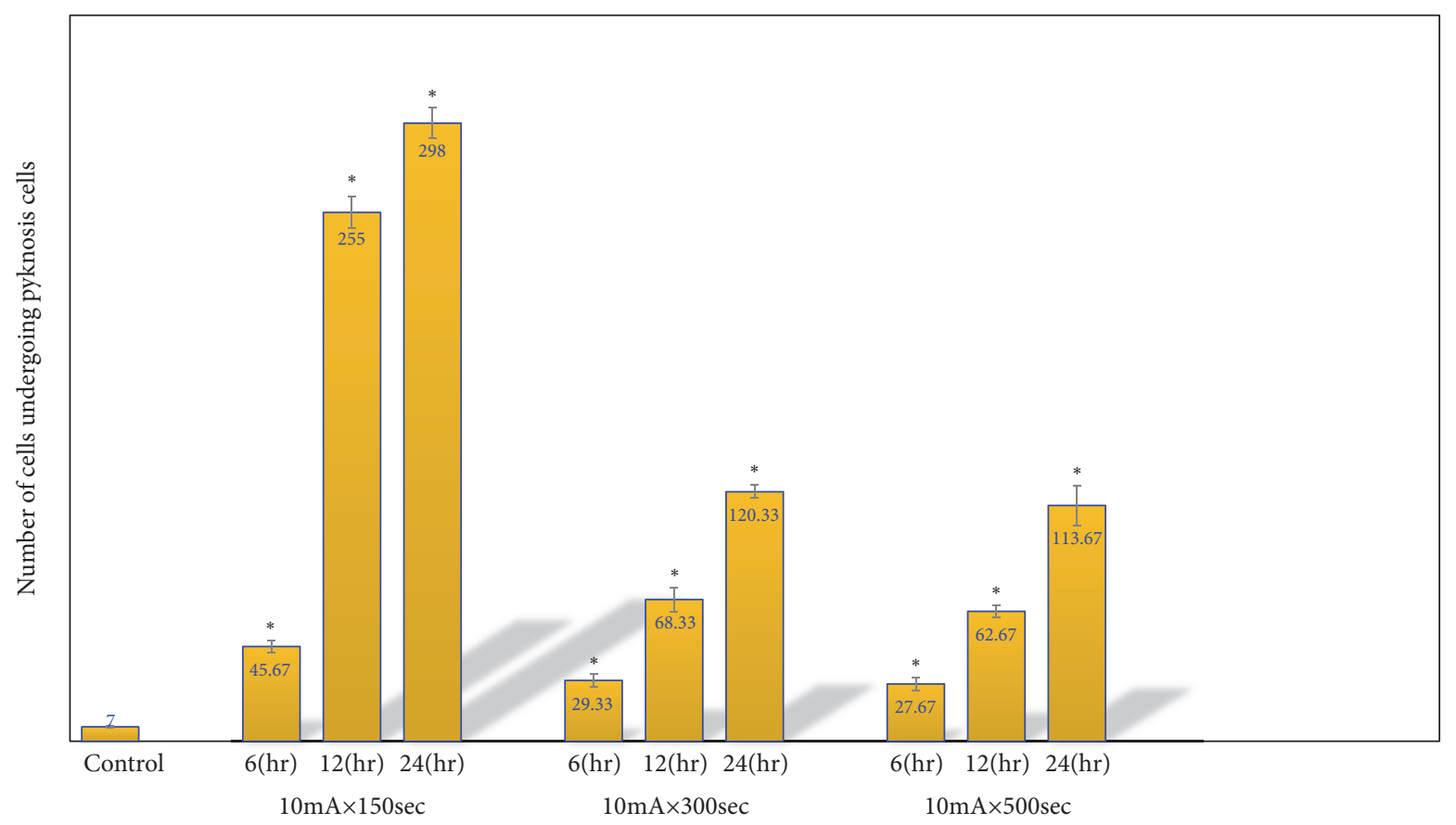

FIGURE 18: Microscopic finding of squamous cell carcinoma $(1 \mathrm{xl} \mathrm{cm})$ occurring on the right upper thigh after inoculation of SCC-7 in $10 \mathrm{~mA} \times 150 \mathrm{sec}$ group, $10 \mathrm{~mA} \times 300 \mathrm{sec}$ group, and $10 \mathrm{~mA} \times 600 \mathrm{sec}$ group. Tissue section taken 6,12 , and 24 hours after treatment. There are many pyknosis neoplastic cells and also some typical spindle cells with mitosis ( $\mathrm{H} \& \mathrm{E}, \mathrm{x} 400)$. $(* p<0.05)$. The results represent \pm S.D. from 8 to 10 mice.

Necrosis occurred within the range where the electrochemical reaction by ECT was prevailing, and because it was reabsorbed, a difference was observed in the tumor weight. This is thought to be based on the same principle as reported by Ashok K. Vijh et al. [19]. As a result, it was suggested that tumor suppressing effect was observed in ECT in Sarcoma180 as tumor suppressing effect was observed in each group than tumor inhibition rate.

In the study using Ehrlich, it is considered that the ascitic tumor appeared more strongly in the electrical response as the reason why clear tumor suppressing effect was observed in each group in the tumor growth measurement. Also, necrosis occurred within the range where the electrochemical reaction by ECT was well-received, and because it was reabsorbed, a difference was observed in the tumor weight. The tumor of Scc-7 was sarcoma and Ehrlich's cancer was ascites. Therefore, the ECT treatment showed a significant decrease in the water content.

In this result as well, it seems that it is based on the same principle as that reported by Ashok et al. and Gu et al. $[19,21]$. As a result, tumor suppression effect was observed in each group than tumor inhibition rate. CR was observed in the $10 \mathrm{~mA} \times 600 \mathrm{sec}$ group. From these results, it was confirmed that ECT has tumor suppressing effect in this study. Moreover, by conducting reresearch in the future, it is considered possible to lead to more reliable research, further development, and use of ECT system. We have great potential for future devices that will enable rapid clinical decisionmaking. ECT reduces medical expenses and patient stress. However, it is also necessary to verify the reliable effect of cancer treatment for each type of cancer related important issues.

\section{Conclusion}

In this study, a significant increase in apoptosis was confirmed in each ECT group compared to the control group. Treatment effects by ECT were also observed in tumor growth measurement studies and tumor weight measurement studies. From these research results, ECT is considered to be effective as a tumor treatment method.

\section{Data Availability}

The data used to support the findings of this study are available from the corresponding author upon request.

\section{Conflicts of Interest}

The authors declare no competing interests regarding the final version of the manuscript.

\section{Authors' Contributions}

All the authors participated in the literature search, interpretation of the articles reviewed, and analysis of the data and review of the manuscript. All the authors have read and approved the paper. 


\section{Acknowledgments}

In this research, the authors acknowledge Ministry of Education, Culture, Sports, Science and Technology Notification No. 71 "Basic Guidelines on Implementation of Animal Experiments in Research Organizations" (June 1, 2006), Ministry of the Environment "Standards on breeding and storage of experimental animals and relief of pain" with reference to the reference.

\section{References}

[1] Y.-H. Gu, H. Choi, T. Yamashita et al., "Pharmaceutical production of anti-tumor and immune-potentiating Enterococcus faecalis-2001 $\beta$-glucans: Enhanced activity of macrophage and lymphocytes in tumor-implanted mice," Current Pharmaceutical Biotechnology, vol. 18, no. 8, pp. 653-661, 2017.

[2] B. E. W. Nordenstrom, "Electrochemical treatment of cancer. I: Variable response to anodic and cathodic fields," American Journal of Clinical Oncology, vol. 12, no. 6, pp. 530-536, 1989.

[3] S. L. David, D. R. Absolom, M. A. Herbert, C. R. Smith, and J. Gams, "Effect of low level direct current on in vivo tumor growth in hamsters," Cancer Research, vol. 45, pp. 5625-5631, 1985.

[4] M. K. Schauble, M. B. Habal, and H. D. Gullick, "Inhibition of experimental tumor growth in hamsters by small direct currents," Archives of Pathology \& Laboratory Medicine, vol. 101, no. 6, pp. 294-297, 1977.

[5] B. E. W. Nordenstroem, "Preliminary clinical trial of electrophoretic ionization in the treatment of malignant tumors," International Research Communications, vol. 6, p. 573, 1978.

[6] B. E. W. Nordenstrom, S. Eksborg, and H. Beving, "Electrochemical treatment of cancer. II. Effect of electrophoretic influence on adriamycin," American Journal of Clinical Oncology, vol. 13, no. 1, pp. 75-88, 1990.

[7] C. E. Humphrey and E. H. Seal, "Biophysical approach toward tumor regression in mice," Science, vol. 130, no. 3372, pp. 388390, 1959.

[8] K. Terai, G.-Z. Dong, E.-T. Oh et al., "Cisplatin enhances the anticancer effect of $\beta$-lapachone by upregulating NQO1," AntiCancer Drugs, vol. 20, no. 10, pp. 901-909, 2009.

[9] X. Yu-Ling, "Advances in the treatment of malignant tumors by electrochemical therapy (ECT)," The European Journal of Surgery, vol. 577, pp. 31-36, 1994.

[10] Y.-L. Xin, F.-Z. Xue, B.-S. Ge, F.-R. Zhao, B. Shi, and W. Zhang, "Electrochemical treatment of lung cancer," Bioelectromagnetics, vol. 18, no. 1, pp. 8-13, 1997.

[11] G. Sersa, D. Miklavcic, U. Batista, S. Novakovic, F. Bobanovic, and L. Vodovnik, "Anti-tumor effect of electrotherapy alone or in combination with interleukin-2 in mice with sarcoma and melanoma tumors," Anti-Cancer Drugs, vol. 3, no. 3, pp. 253260, 1992.

[12] H. Ito and S. S. Hashimoto, "The experimental study of antitumor activity of direct current," Journal of Japan Society for Cancer Therapy, vol. 23, no. 3, pp. 696-702, 1988.

[13] Y. Yen, J.-R. Li, B.-S. Zhou, F. Rojas, J. Yu, and C. K. Chou, "Electrochemical treatment of human KB cells in vitro," Bioelectromagnetics, vol. 20, no. 1, pp. 34-41, 1999.

[14] Y.-H. Gu, Y. Takagi, T. Nakamura et al., "Enhancement of radioprotection and anti-tumor immunity by yeast-derived $\beta$ glucan in mice," Journal of Medicinal Food, vol. 8, no. 2, pp. 154158, 2005.
[15] G. Barbiero, F. Duranti, G. Bonelli, J. S. Amenta, and F. M. Baccino, "Intracellular ionic variations in the apoptotic death of L cells by inhibitors of cell cycle progression," Experimental Cell Research, vol. 217, no. 2, pp. 410-418, 1995.

[16] A. Eastman, "Assays for DNA fragmentation, endonucleases, and intracellular $\mathrm{pH}$ and $\mathrm{Ca} 2+$ associated with apoptosis," Methods in Cell Biology, vol. 46, pp. 41-55, 1995.

[17] K. Ito, K. Kondo, K. Akiyama et al., "Treatment with solid weak direct current conduction therapy for cancer," Cancer \& Chemotherapy Reviews, vol. 22, pp. 1647-1651, 1995.

[18] J. O. Bockris and A. K. Reddy, Modern Electrochemistry, Plenum Press, New York, NY, USA, 1970.

[19] K. Ashok and K. Vijh, "Electrochemical treatment of tumor (ECT): electroosmotic dewatering (EOD) as the primery mechanism," Drying Technology, vol. 17, no. 3, pp. 585-596, 1999.

[20] K. Ito, L. Wong, H. Ando et al., "Pharmacodynamics induced by direct electric current for the treatment of 5-fluorouracil resistant tumor: An animal experiment," International Journal of Colorectal Disease, vol. 16, no. 5, pp. 326-330, 2001.

[21] Y. H. Gu, K. M. Kang, T. Hasegawa et al., "Electrochemical cancer therapy induces apoptosis in SCC-7 tumor of mice," Research Reports of Suzuka University of Medical Science, vol. 11, pp. 22-33, 2004. 


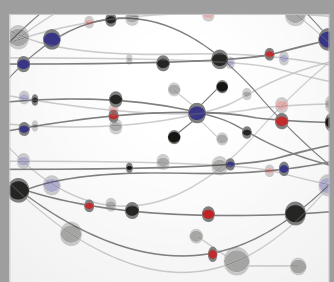

The Scientific World Journal
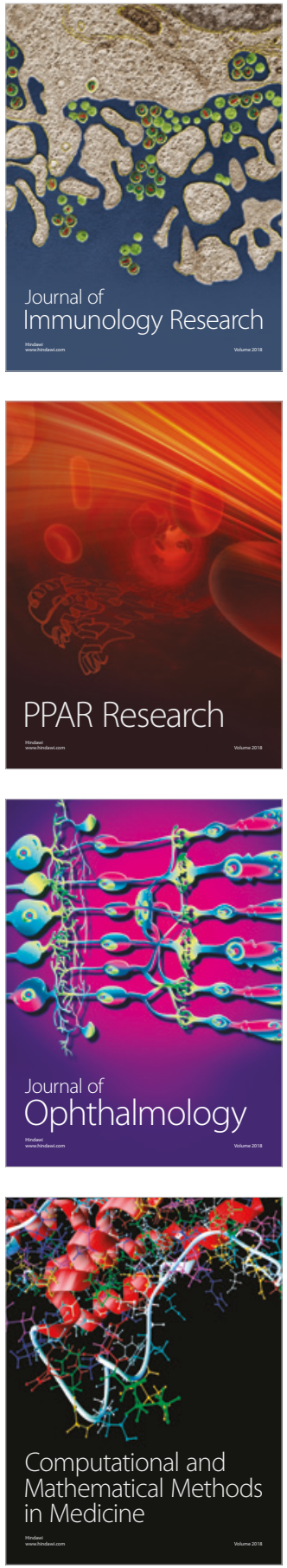

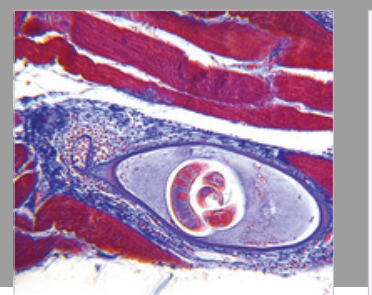

Gastroenterology Research and Practice

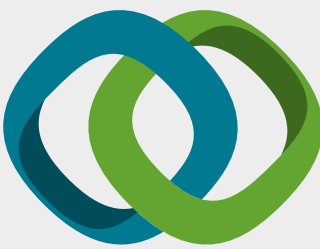

\section{Hindawi}

Submit your manuscripts at

www.hindawi.com
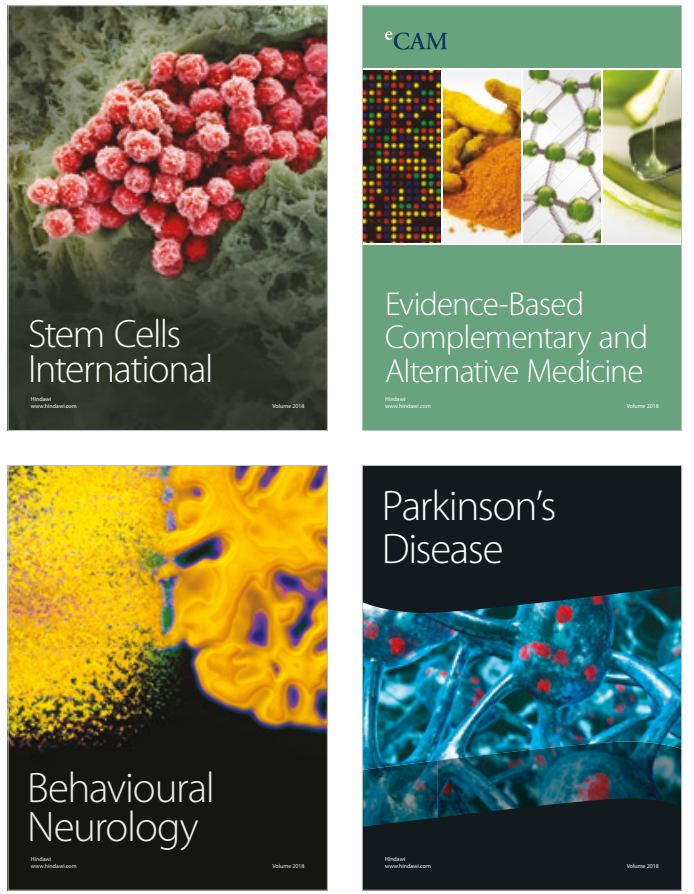

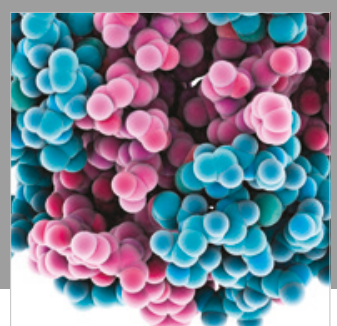

ournal of

Diabetes Research

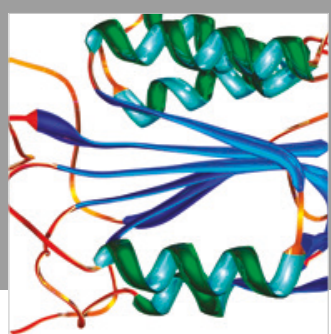

Disease Markers
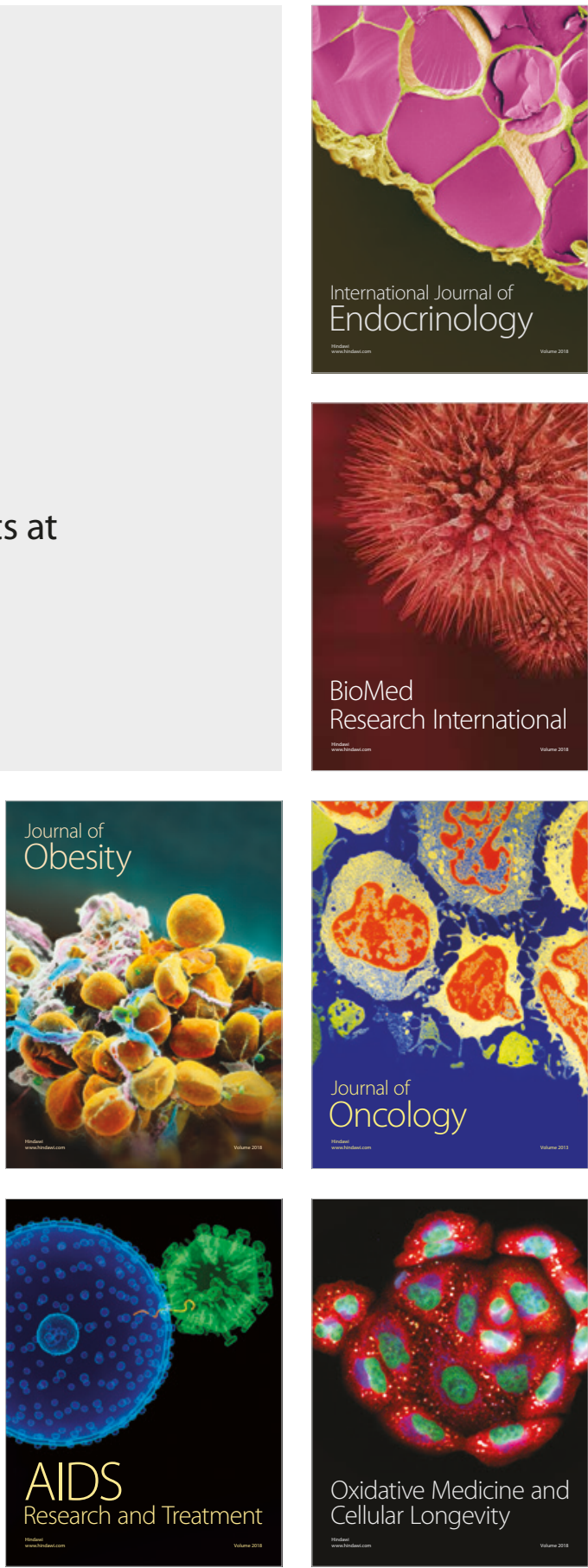